\title{
HELMINTH COMMUNITIES OF TWO GREEN FROGS (RANA PEREZI AND RANA SAHARICA) FROM BOTH SHORES of the Alboran SeA
}

\author{
NAVARRO P.* \& LLUCH J.*
}

\section{Summary:}

The helminth communities of two populations of green frogs from both shores of the Alborán Sea (Western Mediterranean) were studied. Of the 79 frogs examined for helminths, 39 individuals of the species Rana saharica were collected from Bab-Taza (Morocco), and 40 of the species Rana perezi were collected from the Natural Park of the Sierra de Grazalema (Spain). Although the species richness of helminths was identical in the two sampled areas, the differences observed in the structure of the helminth infracommunities were quite important. Statistically, significant differences were found between the species richness and the diversity of the infracommunities of $R$. perezi female population and the other three studied statistical populations. The helminth component communities of these two green frogs can be considered as depauperate, although their infracommunities present interactive features.

KEY WORDS : helminth communities, helminth infracommunities, Rana perezi, Rana saharica, species richness, diversity.

\section{INTRODUCTION}

M ost of the studies related to parasite fauna of European and African amphibians deal mainly with faunistic aspects (Baker, 1981; Murai et al., 1983; Lluch et al., 1986a, 1986b; Kok \& Seaman, 1987; Moravec et al., 1987; Kok,1989; Malashichev, 2000; Galli et al., 2001; Aisien et al., 2003; du Preez et al., 2003).

The revision carried out by Aho (1990) on the helminth community structure of amphibians indicates that the corresponding communities can be highly variable, although they are habitually depauperate and noninteractive in structure.

Various authors (Muzzall, 1991; Goldberg et al., 1995; McAlpine, 1997; Muzzall et al., 2001; Bolek \& Coggins, 2003) consider that amphibian populations provide excellent systems to study ecological concepts related to helminth communities. Therefore, the study of hel-

\footnotetext{
* Department of Zoology, University of Valencia. C/ Dr. Moliner, 50, Burjasot, 46100 Valencia, Spain.

Correspondence: J. Lluch.

Tel.: 34-963544679 - Fax: 34-9635444651.

E-mail: javier.lluch@uv.es
}

Résumé : Communautés d’helminthes de deux POpulations DE GRENOUILLES VERTES (RANA PEREZI ET RANA SAHARICA) DES DEUX RIVAGES DE LA MER D'ALBORÁN

Les communautés d'helminthes de deux populations de grenouilles vertes des rivages de la mer d'Alborán (méditerranéen occidental) ont été étudiées. Des 79 grenouilles examinées pour étudier les helminthes, 39 exemplaires de Rana saharica ont été capturés à Bab-Taza (Maroc), et 40 de l'espèce Rana perezi dans le Parc Naturel Sierra de Grazalema (Espagne). Bien que la richesse des espèces d'helminthes soient identique dans les deux secteurs d'échantillonnage, les différences observées dans la structure des infracommunautés d'helminthes sont assez importantes.

Statistiquement, des différences significatives ont été trouvées entre la richesse en espèces et la diversité des infracommunautés chez les femelles de R. perezi et les trois autres populations statistiques étudiées. Les communautés helmínthiques de ces deux grenouilles vertes peuvent être considérées comme pauvres, bien que leurs infracommunautés présentent des caractéristiques interactives.

MOTS CLÉS : communauté d'helminthes, infracommunauté d'helminthes, Rana perezi, Rana saharica, richesse spécifique, diversité

minth communities in two species of green frogs, Rana perezi Seoane, 1885 and Rana sabarica Bolulenger, 1913, has been carried out. The studied samples were collected from two sites of the Betico-Rifeña Chain, one on each side of the Alborán Sea. The $R$. perezi specimens were taken from the Natural Park of the Sierra de Grazalema (Spain), and the specimens of R. saharica were taken from Bab-Taza (Morocco).

Since the studied ranids are vicariant (Pleguezuelos et al., 2002) and similar in corporal size, physiology and trophic behaviour (Bons \& Geniez, 1996; Esteban et al., 1999), and there are no dietary differences between males and females of both species (Garcia-Paris, 1985; Lizana et al., 1990; Meddeb \& Cheniti, 1998), the observed helminth communities would provide an important information dealing with biotic and abiotic factors which regulate the structure of these communities in relation to the habitat conditions. In addition, as both sampling sites are located in the same mountainous chain and both are directly exposed to the Mediterranean influence, it should be expected that the helmith communities of the host populations were similar and also, as it has been previously commented (Aho, 1990), depauperate and noninteractive in structure. 


\section{MATERIALS AND METHODS}

40 individuals of Rana perezi (18 females and 22 males) were collected in June 1993 from the portion of Cádiz of the Sierra de Grazalema Natural Park (Spain), and 39 specimens of Rana saharica (18 females and 21 males) were collected in September 1997 from Bab-Taza, in the south of Chefchaouen (Western Rif, Morocco). Euthanasia of hosts was performed by an overdose of inhalant anesthetic (ethyl acetate) in accordance with the Canadian Council on Animal Care (1993) guidelines. Data relative to host sex were taken after gonadal inspection and the measures corresponding to the total length $(\mathrm{mm})$ of each frog were recorded. Eventual differences in body length between males and females of the two host species were tested using a one-way analysis of variance (ANOVA). Necropsies of complete specimens were performed and all helminths were counted and identified. Levels of parasitic load and species richness in the four statistical host populations were compared using nonparametric tests, the Kruskal-Wallis test and the Mann-Whitney U test. The parasites were processed following conventional techniques. Trematodes and acanthocephalans were fixed in aqueous Bouin and conserved in $70^{\circ}$ ethanol, stained with Carmine alum, dehydrated and mounted with Canada balsam. Nematodes were fixed and conserved in $70^{\circ}$ ethanol, and were studied using Amann lactophenol wet mounts. All the helminths found, as well as all host carcasses have been deposited in the collection of the Departamento de Zoologia of the University of Valencia (Spain).

The terms prevalence, mean intensity and mean abundance relative to the parasite populations have been used as defined by Bush et al., (1997). A helminth species was considered as common if it occurred in $50 \%$ or more of hosts (Aho, 1990; Muzzall et al., 2001). The mean species richness is the mean number of helminth species per examined frog. The community species richness is the number of helminth species found in an entire host population, and the community abundance is the total number of individual helminths found in an entire host population. Diversity refers to the composition of a sample in terms of helminth species number found in such sample, and it includes a factor that evaluates the evenness in the relative distribution of each helminth species. Evenness is a measurement of the disparity in the number of individuals found for each parasite species. Some authors, such as Poulin (1998), have pointed out some defects of the diversity indexes, indicating that they can be misleading when large parasites coexist in the same host with others of smaller size. In this study we will consider these indexes as simple descriptors of properties of the studied infracommunities, since they can be useful to establish comparisons with other studies and since the parasitic fauna of the green frogs does not usually include large cestodes that mask the results. Values of Brillouin's index (Pielou, 1975) were calculated for measurements of helminth infracommunity diversity and evenness, by means of the DIVERS programme (Krebs, 1989) and the subsequent common logarithms transformation. For component communities, ShannonWiener's index, because it is less biased toward dominant species than other indices (Marcogliese, 2002), and Berger-Parker index were calculated for diversity and dominance analysis respectively, using the programme of Pérez-López \& Solá-Fernández (1993).

A correlation analysis was performed between the size of the individuals from the four statistical populations and the diversity, the evenness, the species richness and the abundance of the corresponding helminth infracommunities, using Spearman's coefficient, due to the low number of values obtained (Ludwig \& Reynolds, 1988).

An eventual influence of the host sex on parasite absolute frequencies, as well as a possible establishment of associations between pairs of helminth species were analysed using G-test, with Wiliam's correction formula. Likewise, Mann-Whitney U test was used to determine whether there was an influence of the host sex on the abundance of parasites.

\section{RESULTS}

T The overall data relative to prevalence, mean intensity and mean abundance of the parasites detected in both sexes of Rana perezi and Rana saharica are summarised in Table I. No helminth species could be considered common in the female hosts of $R$. perezi, and only Rhabdias bufonis was common in the males of this host species. In contrast, Opisthodiscus nigrivasis, Cosmocerca ornata and Spiroxys contortus were common parasite species in the females of $R$. saharica, and $R$. bufonis and C. ornata in their respective males.

In addition, the comparative study of the helminth communities of the two host species allowed to state that, although the abundance of helmiths did not show statistically significant differences (Mann-Whitney U-test, $P=0.566$ ), the total number of parasites was much higher in $R$. perezi (1029) than in $R$. sabarica (538). Table II presents the results provided by the analysis of helminth communities and heminth infracommunities in which host species and host sex were taken into account. Considering a mean number of parasite species, females of $R$. perezi were significantly less infected than the males of the two studied amphibians and than the females of $R$. saharica (Kruskal-Wallis test, $P=0.016$ 


\begin{tabular}{|c|c|c|c|c|}
\hline $\begin{array}{l}\text { Frog species } \\
\text { Helminth species }\end{array}$ & $\begin{array}{l}\text { Location } \\
\text { in host }\end{array}$ & $\begin{array}{c}\text { Mean intensity } \pm \text { SD } \\
\text { (range) }\end{array}$ & Prevalence & $\begin{array}{c}\text { Mean abundance } \\
\pm \text { SD }\end{array}$ \\
\hline \multicolumn{5}{|l|}{ Rana perezi females } \\
\hline D. subclavatus & L. in & $2.50 \pm 2.12(1-4)$ & 2/18 (11.1\%) & $0.28 \pm 0.96$ \\
\hline O. nigrivasis & L. in & $2.00 \pm 0.00$ & $1 / 18(5.5 \%)$ & $0.11 \pm 0.47$ \\
\hline G. microovata & $\mathrm{B}$ & $1.67 \pm 1.15(1-3)$ & $3 / 18(16.6 \%)$ & $0.28 \pm 0.75$ \\
\hline L. nigrovenosus & Sk & $7.00 \pm 0.00(7)$ & $1 / 18(5.5 \%)$ & $0.39 \pm 1.65$ \\
\hline C. europaeus & S. in & $3.50 \pm 2.12(2-5)$ & $2 / 18(11.1 \%)$ & $0.39 \pm 1.24$ \\
\hline P. stromi & S. in & $1.00 \pm 0.00$ & $1 / 18(5.5 \%)$ & $0.06 \pm 0.24$ \\
\hline S. tacapense & S. in & $1.00 \pm 0.00$ & $1 / 18(5.5 \%)$ & $0.06 \pm 0.24$ \\
\hline R. bufonis & $\mathrm{L}$ & $4.14 \pm 3.58(1-11)$ & $7 / 18(38.8 \%)$ & $1.61 \pm 2.97$ \\
\hline S. numidica & S. in & $4.80 \pm 3.77(1-9)$ & $5 / 18(27.7 \%)$ & $1.33 \pm 2.87$ \\
\hline C. ornata & S. in & $18.43 \pm 28.17(1-78)$ & $7 / 18(38.8 \%)$ & $7.17 \pm 19.12$ \\
\hline A. macintoshii & S. in & $12.00 \pm 7.97(1-22)$ & $5 / 18(27.7 \%)$ & $3.33 \pm 6.75$ \\
\hline I. neglecta & Mc & $1.50 \pm 0.71(1-2)$ & 2/18 (11.1\%) & $0.17 \pm 0.51$ \\
\hline \multicolumn{5}{|l|}{ Rana perezi males } \\
\hline D. subclavatus & L. in & $2.20 \pm 1.64(1-5)$ & $5 / 22(22.7 \%)$ & $0.50 \pm 1.19$ \\
\hline O. nigrivasis & L. in & $2.20 \pm 0.45(2-3)$ & $5 / 22(22.7 \%)$ & $0.50 \pm 0.96$ \\
\hline H. kessleri & St & $1.00 \pm 0.00(1)$ & $1 / 22(4.5 \%)$ & $0.05 \pm 0.21$ \\
\hline G. microovata & $\mathrm{B}$ & $7.86 \pm 11.74(1-34)$ & $7 / 22(31.8 \%)$ & $2.50 \pm 7.31$ \\
\hline G. vitelliloba & $\mathrm{B}$ & $1.00 \pm 0.00$ & $2 / 22(9.1 \%)$ & $0.09 \pm 0.29$ \\
\hline C. europaeus & S. in & $8.22 \pm 8.26(2-25)$ & $9 / 22(40.9 \%)$ & $3.36 \pm 6.57$ \\
\hline P. stromi & S. in & $64.00 \pm 75.94(1-171)$ & $5 / 22(22.7 \%)$ & $14.55 \pm 43.04$ \\
\hline S. tacapense & S. in & $6.10 \pm 7.05(1-22)$ & $10 / 22(45.5 \%)$ & $2.77 \pm 5.56$ \\
\hline S. joyeuxi & Mc & $57.00 \pm 0.00(57)$ & $1 / 22(4.5 \%)$ & $2.59 \pm 12.15$ \\
\hline R. bufonis & $\mathrm{L}$ & $6.08 \pm 8.33(1-27)$ & $13 / 22(59.1 \%)$ & $3.59 \pm 7.00$ \\
\hline S. numidica & $S$. in & $1.50 \pm 0.58(1-2)$ & $4 / 22(18.2 \%)$ & $0.27 \pm 0.63$ \\
\hline C. ornata & S. in & $5.11 \pm 4.14(1-14)$ & $9 / 22(40.9 \%)$ & $2.09 \pm 3.62$ \\
\hline A. macintoshii & S. in & $3.13 \pm 2.64(1-8)$ & 8/22 (36.4\%) & $1.14 \pm 2.17$ \\
\hline I. neglecta & $\mathrm{Mc}$ & $1.75 \pm 0.96(1-3)$ & $4 / 22(18.2 \%)$ & $0.32 \pm 0.78$ \\
\hline A. falcatus & S. in & $1.00 \pm 0.00$ & $1 / 22(4.5 \%)$ & $0.05 \pm 0.21$ \\
\hline \multicolumn{5}{|l|}{ Rana saharica females } \\
\hline D. subclavatus & L. in & $14.00 \pm 19.92(2-37)$ & 3/18 (16.7 \%) & $2.33 \pm 8.69$ \\
\hline O. nigrivasis & L. in & $2.29 \pm 0.83(1-3)$ & $14 / 18(77.8 \%)$ & $1.78 \pm 1.22$ \\
\hline G. microovata & $\mathrm{B}$ & $4.33 \pm 4.16(1-9)$ & $3 / 18(16.7 \%)$ & $0.72 \pm 2.19$ \\
\hline L. nigrovenosus & Sk & $1.75 \pm 0.96(1-3)$ & $4 / 18(22.2 \%)$ & $0.39 \pm 0.85$ \\
\hline P. chamaeleonis & S. in & $1.50 \pm 0.71(1-2)$ & 2/18 (11.1\%) & $0.17 \pm 0.51$ \\
\hline S. joyeuxi & Mc & $3.00 \pm 0.00(3)$ & $1 / 18(5.6 \%)$ & $0.17 \pm 0.71$ \\
\hline R. bufonis & $\mathrm{L}$ & $5.00 \pm 5.29(1-16)$ & $7 / 18(38.9 \%)$ & $1.94 \pm 4.02$ \\
\hline S. numidica & S. in & $1.83 \pm 1.17(1-4)$ & 6/18 (33.3\%) & $0,61 \pm 1.09$ \\
\hline C. ornata & S. in & $2.89 \pm 1.54(1-5)$ & $9 / 18(50.0 \%)$ & $1.44 \pm 1.82$ \\
\hline A. macintoshii & S. in & $2.86 \pm 1.86(2-7)$ & $7 / 18(38.9 \%)$ & $1.11 \pm 1.81$ \\
\hline Paracamallanus sp. & St & $1.00 \pm 0.00$ & $1 / 18(5.6 \%)$ & $0.06 \pm 0.24$ \\
\hline S. contortus & Mc & $6.78 \pm 4.21(1-12)$ & $9 / 18(50.0 \%)$ & $3.39 \pm 4.53$ \\
\hline Physalopteridae gen. sp. & S. in; L. in & $2.00 \pm 1.41(1-3)$ & 2/18 (11.1\%) & $0.22 \pm 0.73$ \\
\hline \multicolumn{5}{|l|}{ Rana saharica males } \\
\hline D. subclavatus & L. in & $2.25 \pm 1.50(1-4)$ & $4 / 21(19.0 \%)$ & $0.43 \pm 1.08$ \\
\hline O. nigrivasis & L. in & $1.83 \pm 0.98(1-3)$ & 6/21 (28.6 \%) & $0.52 \pm 0.98$ \\
\hline G. microovata & $\mathrm{B}$ & $2.00 \pm 1.41(1-5)$ & $8 / 21(38.1 \%)$ & $0.76 \pm 1.30$ \\
\hline H. variegatus & $\mathrm{L}$ & $1.00 \pm 0.00$ & $1 / 21(4.8 \%)$ & $0.05 \pm 0.22$ \\
\hline S. joyeuxi & Mc & $8.50 \pm 2.12(7-10)$ & $2 / 21(9.5 \%)$ & $0.81 \pm 2.60$ \\
\hline R. bufonis & $\mathrm{L}$ & $5.18 \pm 5.21(1-15)$ & $11 / 21(52.4 \%)$ & $2.71 \pm 4.54$ \\
\hline S. numidica & S. in & $2.29 \pm 1.25(1-4)$ & $7 / 21(33.3 \%)$ & $0.76 \pm 1.30$ \\
\hline C. ornata & S. in & $3.92 \pm 2.31(1-10)$ & $12 / 21(57.1 \%)$ & $2.24 \pm 2.62$ \\
\hline A. macintoshii & S. in & $5.40 \pm 4.72(2-13)$ & $5 / 21(23.8 \%)$ & $1.29 \pm 3.16$ \\
\hline S. contortus & Mc & $8.44 \pm 14.30(1-46)$ & $9 / 21(42.9 \%)$ & $3.62 \pm 10.01$ \\
\hline Physalopteridae gen. sp. & S. in; L. in & $1.00 \pm 0.00$ & $1 / 21(4.8 \%)$ & $0.05 \pm 0.22$ \\
\hline Pseudabbreviata sp. & S. in & $1.00 \pm 0.00$ & $1 / 21(4.8 \%)$ & $0.05 \pm 0.22$ \\
\hline Agamospirura sp. & $\mathrm{Mc}$ & $1.00 \pm 0.00$ & $1 / 21(4.8 \%)$ & $0.05 \pm 0.22$ \\
\hline
\end{tabular}

Table I. - Location, mean intensity, prevalence and mean abundance of helminth parasites recovered from males and females of Rana perezi and Rana saharica (L. in = large intestine; B = bladder; Sk = skin; S. in = small intestine; $\mathrm{L}=$ lungs; $\mathrm{Mc}=$ muscles; St = stomach). 


\begin{tabular}{|c|c|c|c|c|c|c|}
\hline Host populations & $\begin{array}{c}\boldsymbol{R} \text {. perezi } \\
(\mathrm{n}=40)\end{array}$ & $\begin{array}{l}\text { R. perezi } \\
\text { females } \\
(\mathrm{n}=18)\end{array}$ & $\begin{array}{c}\boldsymbol{R} . \text { perezi } \\
\text { males } \\
(\mathrm{n}=22)\end{array}$ & $\begin{array}{c}\boldsymbol{R} \text { sabarica } \\
(\mathrm{n}=39)\end{array}$ & $\begin{array}{c}\boldsymbol{R} \text {. sabarica } \\
\text { females } \\
(\mathrm{n}=18)\end{array}$ & $\begin{array}{c}\boldsymbol{R} \text {. sabarica } \\
\text { males } \\
(\mathrm{n}=21)\end{array}$ \\
\hline $\mathrm{R}$ & 16 & 12 & 15 & 16 & 13 & 13 \\
\hline A & 1029 & 273 & 756 & 538 & 258 & 280 \\
\hline $\mathrm{H}^{\prime}$ & 2.13 & 1.60 & 1.94 & 2.17 & 2.17 & 2.02 \\
\hline $\mathrm{E}$ & 0.77 & 0.64 & 0.72 & 0.78 & 0.85 & 0.79 \\
\hline d & 0.31 & 0.47 & 0.42 & 0.26 & 0.24 & 0.27 \\
\hline Dominant species & P. stromi & C. ornata & P. stromi & S. contortus & S. contortus & S. contortus \\
\hline $\begin{array}{l}\text { Mean species } \\
\text { richness } \pm \mathrm{SD} \\
\text { (range) }\end{array}$ & $\begin{array}{c}3.03 \\
\pm 2.08 \\
(0-7)\end{array}$ & $\begin{array}{c}2.06 \\
\pm 1.86 \\
(0-6)\end{array}$ & $\begin{array}{c}3.82 \\
\pm 1.94 \\
(0-7)\end{array}$ & $\begin{array}{l}3.49 \\
\pm 1.55 \\
(0-6)\end{array}$ & $\begin{array}{c}3.78 \\
\pm 1.52 \\
(1-6)\end{array}$ & $\begin{array}{c}3.24 \\
\pm 1.58 \\
(0-6)\end{array}$ \\
\hline $\begin{array}{l}\text { Mean helminth } \\
\text { abundance } \pm \text { SD } \\
\text { (range) }\end{array}$ & $\begin{array}{l}25.73 \\
\pm 36.85 \\
(0-175)\end{array}$ & $\begin{array}{c}15.17 \\
\pm 20.32 \\
(0-78)\end{array}$ & $\begin{array}{c}34.36 \\
\pm 44.88 \\
(0-175)\end{array}$ & $\begin{array}{c}13.79 \\
\pm 12.16 \\
(0-58)\end{array}$ & $\begin{array}{c}14.33 \\
\pm 12.73 \\
(1-58)\end{array}$ & $\begin{array}{c}13.33 \\
\pm 11.94 \\
(0-53)\end{array}$ \\
\hline $\begin{array}{l}\text { Mean Brillouin } \\
\text { diversity (ln) } \pm \text { SD } \\
\text { (range) }\end{array}$ & $\begin{array}{c}0.57 \\
\pm 0.44 \\
(0.00-0.52)\end{array}$ & $\begin{array}{c}0.38 \\
\pm 0.40 \\
(0.00-1.19)\end{array}$ & $\begin{array}{c}0.73 \\
\pm 0.42 \\
(0.00-1.52)\end{array}$ & $\begin{array}{c}0.72 \\
\pm 0.36 \\
(0.00-1.26)\end{array}$ & $\begin{array}{c}0.80 \\
\pm 0.34 \\
(0.00-1.26)\end{array}$ & $\begin{array}{c}0.66 \\
\pm 0.37 \\
(0.00-1.17)\end{array}$ \\
\hline $\begin{array}{l}\text { Mean helminth } \\
\text { evenness } \pm \mathrm{SD} \\
\text { (range) }\end{array}$ & $\begin{array}{c}0.58 \\
\pm 0.40 \\
(0.00-1.00)\end{array}$ & $\begin{array}{c}0.43 \\
\pm 0.43 \\
(0.00-1.00)\end{array}$ & $\begin{array}{c}0.70 \\
\pm 0.34 \\
(0.00-1.00)\end{array}$ & $\begin{array}{c}0.74 \\
\pm 0.32 \\
(0.00-1.00)\end{array}$ & $\begin{array}{c}0.81 \\
\pm 0.24 \\
(0.00-1.00)\end{array}$ & $\begin{array}{c}0.68 \\
\pm 0.37 \\
(0.00-1.00)\end{array}$ \\
\hline $\begin{array}{l}\text { Proportion of sample } \\
\text { with } 1 \text { or } 0 \text { helminth } \\
\text { species }\end{array}$ & 0.25 & 0.45 & 0.09 & 0.13 & 0.06 & 0.19 \\
\hline
\end{tabular}

Table II. - Diversity characteristics of biological and statistical populations studied. $\mathrm{R}=$ species richness; $\mathrm{A}=$ helminth abundance; $\mathrm{H}^{\prime}=$ diversity (Shannon-Wiener index); $\mathrm{E}=$ evenness; $\mathrm{d}$ = dominance (Berger-Parker index).

for the four statistical populations; Mann-Whitney Utest, $P=0.008$ for males and females of $R$. perezi, $P=$ 0.007 for the females of both anurous, $P=0.034$ for the females of $R$. perezi and the males of $R$. saharica). The low number of helminth species that infest the females of $R$. perezi determines that the diversity of the their helminth infracommunities is statistically inferior to that of the infracommunities corresponding to both, males of the same species (ANOVA $P=0.010$ ) and statistical populations of females and males of $R$. saharica (ANOVA, $P=0.002$ and $P=0.032$, respectively). Equally, the evenness value for the infracommunities of the statistical population of $R$. perezi females was significantly lower than both, the one for the infracommunities of males of the same species, and the one corresponding to $R$. sabarica females (ANOVA, $P=0.028$ and $P=$ 0.002 , respectively). Nevertheless, this evenness did not significantly vary from the one of the statistical population of $R$. saharica males (ANOVA, $P=0.052$ ).

The differences observed among the four helminth infracommunities can not be attributable to host size, since the comparison of the total length of hosts showed no significant differences among the four studied statistical populations (ANOVA, $P=0.151$ ).

The analysis of host sex in relation to parasite absolute frequencies, showed that the occurrence of the helminths O. nigrivasis and Leptophallus nigrovenosus was significantly more frequent in females of $R$. sabarica than in males of this species (G-test, $P<0.01$ and
$P<0.02$, respectively), and the respective abundances were also higher in females of $R$. saharica than in males of this species (Mann-Whitney U-test, $P=0.002$ and $P=0.025$, respectively). Besides, Sonsinotrema tacapense and Cephalogonimus europaeus occurred more frequently in males of $R$. perezi than in females of this ranid (G test, $P<0.01$ and $P<0.05$, respectively) and, as in the previous case, the respective abundances were also higher in males of $R$. perezi than in females of this species (Mann-Whitney U-test, $P=0.004$ and $P=0.033$, respectively).

In the statistical population of $R$. perezi females, the species richness (Spearman's correlation $r_{\mathrm{s}}=0.637, P=$ $0.005)$ and the abundance of the helminth infracommunities (Spearman's correlation $\mathrm{r}_{\mathrm{s}}=0.72, P=0.001$ ) were positively and significantly correlated with the host size. This correlation was not found in the other three statistical populations of the anurans.

Ten positive and one negative associations between pairs of helminth species were found in $R$. perezi, and one positive and four negative associations were found in R. saharica (Table III).

\section{DISCUSSION}

The comparative study of the helminth infracommunities in the two amphibian species showed that the mean abundance of helminths was 


\begin{tabular}{|c|c|c|c|}
\hline & Sign & $\mathbf{G}_{\mathrm{adj}, 1 \mathrm{df}}$ & $\boldsymbol{P}$ \\
\hline \multicolumn{4}{|l|}{ Rana perezi associations $(n=40)$} \\
\hline O. nigrivasis - C. europaeus & + & 4.34 & $0.05>P>0.02$ \\
\hline O. nigrivasis - C. ornata & + & 5.16 & $0.05>P>0.02$ \\
\hline G. microovata - S. tacapense & + & 6.12 & $0.02>P>0.01$ \\
\hline C. europaeus - S. tacapense & + & 4.90 & $0.05>P>0.02$ \\
\hline C. europaeus $-R$. bufonis & + & 6.21 & $0.02>P>0.01$ \\
\hline C. europaeus - S. numidica & + & 3.92 & $0.05>P>0.02$ \\
\hline P. stromi - A. macintoshii & + & 7.21 & $0.01>P>0.001$ \\
\hline R. bufonis - C. ornata & + & 6.64 & $0.01>P>0.001$ \\
\hline R. bufonis - A. macintosbii & + & 5.56 & $0.02>P>0.01$ \\
\hline C. ornata - I. neglecta & + & 5.16 & $0.05>P>0.02$ \\
\hline O. nigrivasis - A. macintoshii & - & 4.73 & $0.05>P>0.02$ \\
\hline \multicolumn{4}{|l|}{ Rana sabarica associations $(n=39)$} \\
\hline A. macintoshii - Physalopteridae g. sp. & + & 5.20 & $0.02>P>0.01$ \\
\hline O. nigrivasis - D. subclavatus & - & 4.72 & $0.05>P>0.02$ \\
\hline Szidatia joyeuxi - C. ornata & - & 4.22 & $0.05>P>0.02$ \\
\hline S. numidica - S. contortus & - & 4.17 & $0.05>P>0.02$ \\
\hline C. ornata - A. macintoshii & - & 9.74 & $0.01>P>0.001$ \\
\hline
\end{tabular}

Table III. - Associations between pairs of helminth species in Rana perezi and Rana saharica.

higher in $R$. perezi than in $R$. saharica. Females of $R$. perezi presented the particularity of being different from the other three statistical populations in the helminth infracommunities. In fact, species richness and diversity were significantly smaller in the helminth infracommunities of $R$. perezi females. Moreover, the proportions of parasite-free hosts or hosts infected with only one parasite species were significantly higher in these females, which were also different from the other populations in the absence of common parasite species.

Species richness and abundance of the helminth communities (Table II) were lower in the statistical population of $R$. perezi females than in males of this host species. Diversity and evenness values were also lower in $R$. perezi females than in all the other three statistical populations, and the parasite species with the highest value of dominance in females of $R$. perezi was Cosmocerca ornata. In addition, significant correlations of host length/species richness and host length/abundance were exclusively established in the females of R. perezi.

Since some of the previously alluded differences, as those referring to the mean species richness and the diversity of the infracommunities, were statistically significant, it has been attempted to establish the causes of such dissimilarities. According to Kennedy et al. (1986), one of the major factors which contribute to the diversity of helminths is a complex diet of the host that facilitates the ingestion of different intermediate hosts. Among the helminths found, only three species were monoxenous and the cercariae of some trematodes penetrated in the definitive host through the skin, but other helminths invaded their hosts by means of their feeding habits. Although in other studies dealing with the diet of green frogs (Garcia-Paris, 1985; Lizana et al., 1990; Meddeb \& Cheniti, 1998), no dietary differences between male and female anurans were mentioned, it is obvious that larger host individuals must ingest greater amount of prey items. However, the analysis of host size did not highlight any significant difference between $R$. perezi females and the individuals of the other three statistical populations. Therefore, the factor host size can not be used to explain the dissimilarities detected in the helminthofauna of $R$. perezi females. In spite of this, females of $R$. saharica (mean snout-vent length $=53.44+8.43 \mathrm{~mm}$ ) were slightly larger than males (mean snout-vent length $=51.55+$ $9.47 \mathrm{~mm}$ ). This could justify the slightly bigger, but not statistically significant, parasitic load observed in the females of this species.

Various authors (Poulin, 1996; Zuk \& McKean, 1996; Schalk \& Forbes, 1997; Klein, 2000a) affirm that the males of many animal species are more susceptible than their respective females to parasite infections due to hormonal or biological factors. Lees (1962) pointed out that the greatest difference in the levels of parasitization in males and females of Rana temporaria occured when a high level of sex hormone in the blood was observed. However, Plasota (1969) affirms that the differences between males and females of Rana esculenta and Rana terrrestris is not the result of hormonal differences but mostly depends on the biological differences between the two sexes.

Males and females of $R$. saharica were collected in September, far from the reproductive season, when the hormonal levels were low. Besides, specimens of $R$. perezi were collected in June, during the reproductive season, when the hormonal levels were presumably the highest. Therefore, the hormonal factor and the estrogen protection against determined parasites could be the cause of the observed dissimilarities. This explanation is 
consistent with the fact that there were very slight differences between the helminth infracommunities of males and females of $R$. saharica, with an expected low level of estrogen in the females. These differences were evident and statistically significant between the helminth infracommunities of males and females of $R$. perezi whose females would contain high levels of estrogens. It is also necessary to take into consideration that exposure to environmental and social stressors can suppress immune function and increase susceptibility to disease (Klein, 2000b). Several studies in Amphibia illustrate that courtship displays are costly from the metabolism point of view, being able to increase male susceptibility to infection (Taigen \& Wells, 1985; Pfennig \& Tinsley, 2002). This factor could have contributed to increase the parasitic load of $R$. perezi males.

The results obtained by Muzzall (1991) and McAlpine (1997), in relation to the analysis of the helminth communities of different holarctic frogs, are consistent with those provided hereby on the helminth infracommunities of green frogs, although the diversity and the evenness values are slightly higher in the present study. Nevertheless, the species richness, the diversity and the abundance values of the helminth infracommunities were very low in these studied green frogs compared to the values found in the helminth infracommunities of Rana clamitans from Michigan, USA (Muzzall et al., 2001). These authors set that the helminth communities of $R$. clamitans were depauperate and noninteractive.

The present study shows that the helminth communities of the examined frogs were depauperate, but they should be considered as interactive, since there were (Table III) many positive and negative associations built up between pairs of helminths of both $R$. perezi and R. saharica populations. Lotz \& Font (1994) and Poulin (1997) indicated that a high proportion of rare parasite species (prevalence less than $10 \%$ ) in the component community, can lead to an excess of negative associations, and that a high proportion of common species (prevalence greater than $90 \%$ ), can produce an excess of positive associations. Among the obtained results, the studied component communities do not show unusual proportions of rare or common species, for what they can represent interactive communities. Positive interactions in $R$. perezi can be given because the presence of a parasite species, can facilitate the infection by other species and negative interactions in $R$. sabarica can have their origin in factors such as competitive exclusion.

\section{ACKNOWLEDGEMENTS}

W

e thank Dr. J.D. Acuña for his methodological advice. Thanks are extended to Dr J. Martin for linguistic corrections in the manus- cript. The authors declare that the experiments comply with the current laws of the country in which they were performed.

\section{REFERENCES}

AHo J.M. Helminth communities of amphibians and reptiles: comparative approaches to understanding patterns and processes. In: Parasite communities patterns and processes. Esch G., Bush A. \& Aho J. (eds), Chapman and Hall, London, 1990, 157-159.

Aisien S.O., Ajakaiye F.B. \& Braimoh K. Helminth parasites of anurans from the savannah-mosaic zone of south-western Nigeria. Acta Parasitologica, 2003, 48, 47-54.

BAKER M.R. On three Oswaldocruzia spp. (Trichostrongyloidea: Molineidae) in amphibians from Africa. Canadian Journal of Zoology, 1981, 59, 246-251.

Bolek M.G. \& CogGins J.R. Helminth community structure of sympatric eastern American toad, Bufo americanus americanus, northern leopard frog, Rana pipiens, and bluespotted salamander, Ambystoma laterale, from southeastern Wisconsin. Journal of Parasitology, 2003, 89, 673-680.

Bons J. \& Geniez P. Anfibios y reptiles de Marruecos (incluido Sáhara Occidental). Atlas biogeográfico. Asociación Herpetológica Española, Barcelona, 1996, 320 p.

Bush A.O., Lafferty K.D., Lotz J.M. \& Shostak A.W. Parasitology meets ecology on its own terms: Margolis et al., revisited. Journal of Parasitology, 1997, 83, 575-583.

Canadian Council on Animal Care. Guide to the Care and Use of Experimental Animals, Vol. 1, $2^{\text {nd }}$ ed. Olfert E.D., Cross B.M. \& McWilliam A.A. (eds), Canadian Council on Animal Care, Ontario, Canada, 1993, 211 p.

Du Preez L.H., Tinsley R.C. \& DE SA R. Polystomatidae (Monogenea) of Southern African Anura: Eupolystoma vanasi n. sp. parasitic in Schismaderma carens (Smith). Systematic Parasitology, 2003, 54, 71-79.

Esteban M., García-París M., Buckley D. \& Castanet J. Bone growth and age in Rana saharica, a water frog living in a desert environment. Annales Zoologici Fennici, 1999, 36, 53-62.

Galli P., Gentilli A., Santagostino M. \& Crosa G. Contributo alla conoscenza dell'elmintofauna di Bufo bufo (Linnaeus, 1758) provenienti dai bacini di Endine e del Segrino. Pianura 2001, 13, 85-88.

Garc ÍA-PAR Ís M. Los anfibios de España. Ministerio de Agricultura, Pesca y Alimentación, Madrid, 1985, 287 p.

Goldberg S.R., Bursey C.R. \& Ramos I. The Component Parasite Community of Three Sympatric Toad Species, Bufo cognatus, Bufo debilis (Bufonidae), and Spea multiplicata (Pelobatidae) from New Mexico. Journal of the Helminthological Society of Washington, 1995, 62, 57-61.

Kennedy C.R., Bush A.O. \& AhO J.M. Patterns in helminth communities: why are birds different? Parasitology, 1986, 93, 205-215.

KLEIN S.L. The effects of hormones on sex differences in infection: from genes to behavior. Neuroscience and Biobehavioral Reviews, 2000a, 24, 627-638. 
KLEIN S.L. Hormones and mating system affect sex and species differences in immune function among vertebrates. Behavioural Processes, 2000b, 51, 149-166.

KoK D.J. Polystomatid monogenean parasites of Anura: life cycle adaptations. Journal of the Herpetological Association of Africa, 1989, 36, 38-40.

Kon D.J. \& SEAman M.T. Polystomatidae (Monogenea) parasitic in the anuran genus Natalobatrachus in South Africa. South African Journal of Zoology, 1987, 22, 258-263.

KreBs C.J. Ecological methodology. Harper and Row, New York, 1989, $654 \mathrm{p}$.

LEEs E. The inicidence of helminth parasites in a particular frog population. Parasitology, 1962, 52, 95-102.

Lizana M., Pérez-Mellado V. \& Ciudad M.J. Analysis of the structure of an amphibian community in the Central System of Spain. Herpetological Journal, 1990, 1, 435-446.

LOTZ J.M. \& FONT W.F. Excess positive associations in communities of intestinal helminths of bats: a refined null hypothesis and a test of the facilitation hypothesis. Journal of Parasitology, 1994, 80, 398-413.

Ludwig J.A. \& ReYNolds J.F. Statistical ecology: a primer on methods and computing. A Wiley-Interscience Publications, John Wiley \& Sons, New York, 1988, 337 p.

Lluch J., Roca V. \& Navarro P. Helmintofauna de anfibios del Levante Iberico. Trematodos de Rana perezi Seoane, 1885. Boletín de la Real Sociedad Española de Historia Natural, 1986a, 81, 43-49.

Lluch J., Roca V. \& NAvarro P. Contribución al conocimiento de la helmintofauna de los herpetos ibericos. 3. Digenea Paramphistomidae, Hemiuridae, Gorgoderidae, Plagiorchiidae, Haematoloechidae y Cephalogonimidae de Rana perezi Seoane, 1885 (Amphibia: Ranidae). Revista Ibérica de Parasitología, 1986b, 46, 387-392.

MaLASHICHEV Y.B. On parasites of the yellow-bellied toad (Bombina variegata). Advances in Amphibian Research in the Former Soviet Union, 2000, 5, 289-290.

Marcogliese D.J. Parasites of fishes in fresh water. Parasitology Module Steering Committee, Parasitology Section, Canadian Society of Zoologists. Ecological Monitoring and Assessment Network (EMAN). Protocols for Measuring Biodiversity, Environment Canada, Montreal, 2002, 20 p.

McAlPINE D.F. Helminth communities in bullfrogs (Rana catesbeiana), green frogs (Rana clamitans) and leopard frogs (Rana pipiens) from New Brunswick, Canada. Canadian Journal of Zoology, 1997, 75, 1883-1890.

Meddeb C.\& Cheniti T.L. Régime alimentaire de deux populations de grenouille verte de Tunisie Rana saharica Boulenger, 1913 (Amphibiens, Anoures, Ranidae). Bulletin de la Société zoologique de France, 1998, 123, 3-14.

Moravec F., Barus V. \& Rysavy B. Some parasitic nematodes, excluding Heterakidae and Pharyngodonidae, from amphibians and reptiles in Egypt. Folia Parasitologica, 1987, 34, 255-267.

Murai E., Sulgostowska T., Matskasi I., Meszaros F. \& MolNAR K. Parasitic helminths of vertebrates (fishes, amphibians, reptiles and birds) in the Hortobagy National Park. Natural History of the National Parks of Hungary, 1983, 2, 15-30.
Muzzall P.M. Helminth infracommunities of the frogs Rana catesbeiana and Rana clamitans from Turkey Marsh, Michigan. Journal of Parasitology, 1991, 77, 366-371.

Muzzall P.M., Guillillland M.G. 3rd., Summer C.S. \& Mehne C.J. Helminth communities of green frogs Rana clamitans Latreille, from southwestern Michigan. Journal of Parasitology, 2001, 87, 962-968.

PÉREZ-LoPez F.J. \& SolÁ-FERnÁndez F.M. DIVERS: Programa para el cálculo de los índices de diversidad, 1993. On-line informatic program available from http://perso.wanadoo.es/jp1/descargas.htm [with access February 2, 2006].

Pfennig K.S. \& Tinsley R.C. Different mate preferences by parasitized and unparasitized females reduces sexual selection. Journal of Evolutionary Biology, 2002, 15, 399-406.

PIElou E.C . Ecological diversity. Wiley-Interscience, New York, 1975, $165 \mathrm{p}$.

Plasota K. The effect of some ecological factors on the parasitofauna of frogs. Acta Parasitologica Polonica, 1969, 16, 47-60.

Pleguezuelos J.M., Márquez R. \& Lizana M. (eds). Atlas y Libro Rojo de los Anfibios y Reptiles de España. Dirección General de Conservación de la Naturaleza - Asociación Herpetológica Española (2 $2^{\mathrm{a}}$ impresión), Madrid, 2002, 585 p.

Poulin R. Sexual inequalities in helminth infections: a cost of being male? American Naturalist, 1996, 147, 287-295.

Poulin R. Species richness of parasite assemblages: evolution and patterns. Annual Review of Ecology and Systematics, 1997, 28, 341-358.

Poulin R. Evolutionary ecology of parasites: from individuals to communities. Chapman \& Hall, London, United Kingdom, 1998, 212 p.

SCHALK G. \& Forbes M.R. Male biases in parasitism of mammals: effects of study type, host age, and parasite taxon. Oikos, 1997, 78, 67-74.

TAigen T.L. \& Wells K.D. Energetics of vocalization by ananuran amphibian (Hyla versicolor). Journal of Comparative Physiology B: Biochemical, Systemic, and Environmental Physiology, 1985, 155, 163-170.

ZuK M. \& MCKEAN K.A. Sex differences in parasite infections: Patterns and processes. International Journal for Parasitology, 1996, 26, 1009-1024.

Reçu le 9 février 2006 Accepté le 5 juillet 2006 